\title{
INFORME DEL SIMPOSIO CIEN AÑOS DE LAS RELACIONES DIPLOMÁTICAS CHECO-ESPAÑOLAS (Praga, 18 de octubre de 2019)
}

El 18 de octubre de 2019 se celebró en el Palacio Spork el simposio Cien años de las relaciones diplomáticas checo-españolas, organizado por el Centro de Estudios Ibero-Americanos para conmemorar el centenario de las relaciones diplomáticas checo-españolas.

El simposio fue inaugurado por el embajador de España en la República Checa, el Excmo. Sr. Ángel Lossada Torres-Quevedo. En su discurso el embajador subrayó la necesidad de mantener y reforzar los lazos entre la República Checa y España en el futuro, ya que el último centenario de las relaciones diplomáticas se vio afectado por las dos dictaduras en ambos países. En este sentido, el embajador recordó la importancia de los estudios hispánicos en la República Checa y dio las gracias a los hispanistas checos por el gran trabajo que realizan en la investigación y difusión de la lengua y la cultura española. Para concluir, el embajador comentó la situación política actual en España, concretamente la división de la sociedad por la cuestión catalana. El embajador sostuvo que la tensa situación política en Cataluña se podía superar solo con la colaboración de todos los españoles, independientemente de la lengua que hablen.

El diplomático Milan Jakobec resumió el pasado centenario de las relaciones diplomáticas desde los primeros contactos oficiales hasta la actualidad. Las relaciones, formalizadas ya en los primeros años, tras el nacimiento de la República Checoslovaca en 1918 e interrumpidas por el período de las dictaduras, volvieron a profundizarse, sobre todo, después de la transición democrática en España y la Revolución de Terciopelo en Checoslovaquia.

El historiador y especialista en las relaciones checo-españolas durante la Edad moderna, Pavel Marek, de la Universidad de Pardubice enfocó su ponencia en los siglos XVI y XVII, es decir, en la época cuando los contactos entre el Imperio y la Monarquía Católica se basaban en la dinastía gobernante común: la Casa de los Habsburgo, y la política contrarreformista. Las relaciones fueron fomentadas no solo por las embajadas, sino también por las órdenes religiosas o las familias nobles centroeuropeas, como los Pernstein, los Lobkowicz o los Dietrichstein, y sus lazos matrimoniales con las damas españolas.

La hispanista Anna Mištínová de la Universidad Carolina dedicó su presentación a Hexaglosson praguense, diccionario y manual de idiomas del siglo XVI. El diccionario, que contiene seis idiomas, destaca por ser el único conocido hasta ahora -de las obras de este tipo- que combina tanto la versión española como la checa. La doctora Mištínová describió su estructura y característica e intentó aclarar su origen e influencias. Mencionó también algunos datos desconocidos relacionados con el fechado, autoría y originalidad.

Simona Binková, investigadora del Centro de Estudios Ibero-Americanos enfocó su ponencia en los viajeros checos en España desde la Edad Media hasta el siglo XVIII. Presentó varios motivos que tenían los viajeros durante la Edad Media para ir a España, como, por ejemplo, los estudios, las razones religiosas y los fines diplomáticos. Con respecto a los siglos siguientes, la doctora Binková mencionó también los enlaces matrimoniales entre las familias nobles centroeuropeas y españolas o el fenómeno de Grand tour. Para finalizar, recalcó los cambios en el siglo XIX causados por las nuevas posibilidades en el transporte y la diferente motivación para viajar.

Pavel Štěpánek, historiador del arte y catedrático de la Universidad Palacký de Olomouc, presentó una charla sobre la exposición de las obras de Francisco Goya realizada en 1933 en la Galería Mánes. El profesor Štěpánek destacó el gran apoyo que gozó la exposición por parte de las clases más altas, tanto de la sociedad checoslovaca como de la española y, asimismo, resumió el interés por la obra goyesca en Checoslovaquia. 
El simposio continuó, después de la pausa, con la presentación de Luis Montilla, historiador español afincado en Praga. Se concentró en las relaciones entre España y Checoslovaquia en la época de entreguerras y las analizó en el contexto internacional. Explicó los cambios de las relaciones bilaterales, iniciadas con el nacimiento de la República Checoslovaca y, asimismo, describió las actividades de los diplomáticos y el desarrollo económico en ambos países, relevante para los contactos bilaterales. Subrayó el notable mejoramiento de las relaciones durante el período de la Segunda República Española.

Hana Bortlová, investigadora del Instituto de Historia Contemporánea de la Academia de Ciencias de la República Checa, recordó una de las etapas muy importantes de las relaciones checo-españolas: la presencia de los checos y eslovacos en las interbrigadas, centrándose en la historiografía checoslovaca y checa. Como recordó la doctora Bortlová, las valoraciones de las interbrigadas cambiaron varias veces, dependiendo del contexto político y social, yendo de lo positivo, a finales de los años 40, a lo casi ignorado en los años 90.

Maroš Timko, doctorando del Centro de Estudios Ibero-Americanos abarcó en su ponencia el tema del exilio checo y eslovaco en la España franquista. Advirtió de la interesante correlación entre el nacionalismo-separatismo eslovaco, el catolicismo, la crítica anticomunista y la política exterior española, mencionando varios personajes importantes del exilio eslovaco, como el diplomático Jozef Cieker o su discípulo Štefan Glejdura.

Anežka Charvátová, hispanista y traductora de la Universidad Carolina, analizó la situación de la literatura española en el mercado checo después del 1989. Advirtió que los objetivos de las casas editoriales se orientan más al éxito comercial que a la búsqueda de las obras de alta calidad. Los intereses comerciales se reflejan también en la calidad de las traducciones. Charvátová mencionó que los editores checos suelen favorecer a los autores españoles frente a las autoras.

La ponencia del profesor Josef Opatrný, historiador del Centro de Estudios Ibero-Americanos se dedicó a la imagen de España en los textos de los viajeros y escritores checos en los años veinte y treinta del siglo $\mathrm{XX}$, en una época cuando se produjo un aumento considerable del turismo. El profesor Opatrný destacó varios títulos y autores que gozaron de popularidad en Checoslovaquia en aquella época, por ejemplo, los artículos de Vlastimil Kybal, "Výlet do Španěl" [Viaje a España] de Karel Čapek, "Pout' do Španělska" [Peregrinaje por España] de Jaroslav Durych y muchos más. España estaba, en general, retratada como un país atractivo, con una historia rica y fascinante.

El simposio terminó con la presentación de la profesora Jana Králová, catedrática de la Universidad Carolina en Praga, sobre el tema de las antologías de textos traductológicos. Analizó el objetivo de este tipo de recopilaciones, que es recontextualizar los textos teóricos de la traductología, en este caso checa y española, y dotar a la traductología de una perspectiva histórica. Asimismo, mencionó sus actividades y publicaciones en este ámbito, sobre todo, las recopilaciones de textos del profesor Levý.

por Anna Nováková y Ana Libánská (Escrito en español por las autoras) 